\title{
PERSPEKTIF PERTANGGUNGJAWABAN PIDANA KORPORASI SEBAGAI PELAKU TINDAK PIDANA KORUPSI
}

\author{
Eddy Rifai* \\ Bagian Hukum Pidana, Fakultas Hukum Universitas Lampung, Bandar Lampung \\ Gedung Meneng, Bandar Lampung, Lampung, 35145
}

\begin{abstract}
This study examines the perspectives of corporate criminal responsibility as perpetrators of corruption. The research method used normative juridical approach and empirical jurisdiction. The results showed that the regulation of corporate criminal responsibility in criminal corruption has been regulated in the legislation of corruption but are rarely applied in practice. The reluctance of the Public Prosecutor filed a corporate offender to court, because the punishment to be imposed on the corporation only in the form of criminal penalties that have less than the deterrent effect of the death penalty or imprisonment and hardships refutation against the corporation as part elements of the law rather than to prove the guilt of a person accused acquitted result.
\end{abstract}

Keywords: criminal liability, corporate, corruption.

\section{Intisari}

Penelitian mengkaji tentang perspektif pertanggungjawaban pidana korporasi sebagai pelaku tindak pidana korupsi. Metode penelitian menggunakan pendekatan yuridis normatif dan yuridis empiris. Hasil penelitian menunjukkan bahwa pengaturan pidana tentang pertanggungjawaban pidana korporasi dalam tindak pidana korupsi telah diatur dalam peraturan perundang-undangan tindak pidana korupsi tetapi jarang diterapkan dalam praktik. Keengganan Jaksa Penuntut Umum mengajukan pelaku korporasi ke pengadilan, karena pemidanaan yang akan dikenakan kepada korporasi hanya berupa pidana denda yang kurang mempunyai efek penjera daripada pidana mati atau penjara dan kesulitan pembuktian "kesalahan" korporasi sebagai bagian unsur melawan hukum daripada membuktikan kesalahan orang perorang yang berakibat terdakwa dibebaskan.

Kata Kunci: pertanggungjawaban pidana, korporasi, tindak pidana korupsi.

\section{Pokok Muatan}

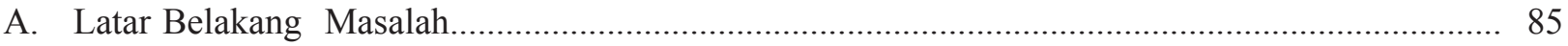

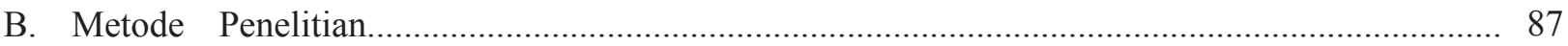

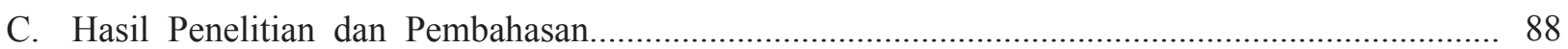

1. Pertanggungjawaban Korporasi dalam Tindak Pidana Korupsi........................................... 88

2. Faktor Penghambat Pertanggungjawaban Korporasi dalam Tindak Pidana Korupsi................ 90

3. Perspektif Pertanggungjawaban Pidana Korporasi dalam Tindak Pidana Korupsi.... 93

C. Kesimpulan. 96

Alamat korespondensi: eddyrifai@ymail.com 


\section{A. Latar Belakang Masalah}

Korupsi di Indonesia terjadi secara sistematik dan meluas sehingga tidak hanya merugikan keuangan negara, tetapi juga telah melanggar hak-hak sosial dan ekonomi masyarakat secara luas, maka pemberantasan korupsi perlu dilakukan dengan cara luar biasa. ${ }^{1} \quad$ Korupsi-korupsi yang dilakukan secara sistematik dapat dilihat dalam kasus Bantuan Likuiditas Bank Indonesia (BLBI), ${ }^{2}$ Bank Century, ${ }^{3}$ dan Proyek Hambalang ${ }^{4}$ yang melibatkan pihak perencana/penganggaran keuangan/pengawas (DPR) dan pelaksana proyek (pemerintah). Korupsi dikatakan meluas karena terjadi pada hampir setiap institusi pemerintah (kementerian dan pemerintah daerah), DPR dan DPRD serta lembaga yudikatif (kepolisian, kejaksaan dan pengadilan) sehingga telah membuat korupsi sebagai suatu budaya (corruption was away of life). ${ }^{5}$

Perhatian dunia internasional terhadap korupsi terdapat dalam Kongres $\mathrm{PBB}$ ke- 8 tahun 1990 di Havana Cuba yang menyoroti dimensi kejahatan seperti: (1) masalah urban crime; (2) crime against the nature and the environmental; (3) corruption keterkaitannya dengan economic crime, organized crime, illicit trafficking in narcotic, drugs and psychotropic substances, termasuk juga masalah money laundering; (4) crime against movable cultural property (cultural heritage); (5) computer related crime; (6) terrorism; (7) domestic violence; (8) instrumental use children in criminal activities. ${ }^{6}$ Khususnya mengenai masalah korupsi, Kongres ke- 8 menyatakan sangat perlunya hal ini diperhatikan mengingat "corrupt activities of public official": a. can destroy the potential effectiveness of all types of governmental programmes (dapat menghancurkan efektivitas potensial dari semua jenis program pemerintah); b. hinder development (dapat mengganggu/menghambat pembangunan); c. victimize individuals and groups (menimbulkan korban bagi individual maupun kelompok). ${ }^{7}$

Kongres dalam kaitannya dengan hal di atas, menghimbau kepada negara-negara anggota PBB untuk menetapkan strategi anti-korupsi sebagai prioritas utama di dalam perencanaan pembangunan sosial dan ekonomi (di dalam dokumen A/CONF. 144/L.13 disebutkan "The designation of anti-corruption strategies as high priorities in economic and social development plans"), serta mengambil tindakan terhadap perusahaanperusahaan yang terlibat dalam tindak pidana korupsi. ${ }^{8}$ Dokumen Kongres PBB ke-9 tahun 1995 menyatakan: Korporasi asosiasi kriminal atau individu mungkin terlibat dalam "penyuapan para pejabat" untuk berbagai alasan yang tidak semuanya bernilai ekonomis. Tetapi, dalam banyak kasus, masih saja terdapat penyuapan untuk mencapai keuntungan ekonomis. Tujuannya ialah membujuk para pejabat untuk memberikan berbagai bentuk perlakuan khusus/istimewa (preferential treatment) antara lain: (a) memberikan

Penjelasan Umum Undang-Undang Nomor 20 Tahun 2001 tentang Perubahan Undang-Undang Nomor 31 Tahun 1999 tentang Pemberantasan Tindak Pidana Korupsi (Tambahan Lembaran Negara Republik Indonesia Nomor 4150).

2 Bantuan Likuiditas Bank Indonesia (BLBI) adalah skema bantuan pinjaman BI terhadap bank-bank yang mengalami krisis likuiditas akibat krisis moneter di Indonesia tahun 1998. BI telah menyalurkan dana sebesar Rp 147 triliun kepada 48 bank. Dari hasil audit BPK telah terjadi penyimpangan sebesar Rp 138 triliun.

KPK telah menetapkan 2 (dua) orang Deputi Gubernur non-aktif BI, yaitu BM dan SF sebagai tersangka kasus penyimpangan dana talangan (bail out) BI kepada Bank Century.

4 KPK telah menetapkan beberapa tersangka dalam kasus Proyek Hambalang, dari kalangan pengusaha, anggota DPR, dan pemerintah, serta 1 orang menteri aktif, yaitu AM yang kemudian mengundurkan diri dari jabatannya selaku Menpora.

Penelitian Richard Hooley di Filipina yang menggambarkan korupsi terjadi pada setiap intansi pemerintah selama rejim Marcos berkuasa telah membudaya (corruption was away of life). Lihat Baharuddin Lopa, 2001, Kejahatan Korupsi dan Penegakan Hukum, Penerbit Buku KOMPAS, Jakarta, hlm. 77. Lihat juga Apolinario D. Bruselas, "Corruption: The Philippine Experience” dalam UNAFEI, 1998, Resource Material Series No. 52, Tokyo, hlm. 101.

Barda Nawawi Arief, 1996, Bunga Rampai Kebijakan Hukum Pidana, Alumni, Bandung, hlm. 18.

Ibid., hlm. 19.

Terdapat tiga strategi pemberantasan korupsi yang disarankan, yaitu: (1) adanya political will pemerintah; (2) penyempurnaan penegakan hukum pidana; dan (3) pressure masyarakat. 
kontrak (awarding a contract); (b) mempercepat atau memperlancar izin (expediting a license); (c) membuat perkecualian-perkecualian atau menutup mata terhadap pelanggaran peraturan (making exceptions to regulatory standards or turning a blind eye to violations of those standards). ${ }^{9}$

Keterlibatan perusahaan-perusahaan (korporasi) dalam tindak pidana korupsi bukan rahasia umum lagi. Beberapa kasus yang sedang dalam proses peradilan pidana adalah kasus pengusaha besar SHM, ${ }^{10}$ Simulator SIM Mabes POLRI, ${ }^{11}$ IM2 Indosat ${ }^{12}$ dan beberapa kasus yang pelakunya telah dijatuhi pidana seperti kasus Nazarudin ${ }^{13}$ dan Sisminbakum. ${ }^{14}$

Undang-Undang Nomor 31 Tahun 1999 yang telah diubah dengan Undang-Undang Nomor 20 Tahun 2001 tentang Pemberantasan Tindak Pidana Korupsi (UU No. 31/1999) menentukan selain orang, korporasi merupakan subyek hukum/ pelaku tindak pidana ${ }^{15}$ Tetapi dalam praktiknya, penerapan pertanggungjawaban pidana terhadap korporasi sebagai pelaku tindak pidana korupsi jarang dilakukan oleh aparat penegak hukum. Padahal dengan mempertanggungjawabkan korporasi akan didapat manfaat: (1) rapat menimbulkan efek jera terhadap korporasi untuk tidak terlibat dalam tindak pidana korupsi; (2) penegakan hukum pidana akan lebih berkeadilan karena menjangkau pelaku-pelaku lainnya yang turut bertanggungjawab dalam korporasi seperti komisaris, direktur, pegawai, pihak terafiliasi ${ }^{16}$ dan holding company; ${ }^{17}$ (3) penjatuhan pidana tambahan yang lebih luas, di samping pembayaran uang pengganti, juga perampasan barang bergerak yang berwujud atau yang tidak berwujud; penutupan seluruh atau sebagian perusahaan; dan pencabutan seluruh atau sebagian hak-hak tertentu atau sebagian keuntungan tertentu yang telah atau dapat diberikan pemerintah. ${ }^{18}$

Menurut Muladi dan Dwidja Priyatno ${ }^{19}$ pembenaran pertanggungjawaban korporasi sebagai pelaku tindak pidana dapat didasarkan hal-hal sebagai berikut: (1) atas dasar falsafah integralistik, yakni segala sesuatu yang diukur atas dasar keseimbangan, keselarasan, dan keserasian antara kepentingan individu dan kepentingan sosial; (2) atas dasar kekeluargaan dalam Pasal 33 UndangUndang Dasar 1945; (3) untuk memberantas anomie of success (sukses tanpa aturan); (4) untuk perlindungan konsumen; dan (5) untuk kemajuan teknologi. Terhadap pelaku-pelaku korporasi seyogyanya penegakan hukum pidana menggunakan pertanggungjawaban korporasi sebagaimana ditentukan dalam Pasal 20 UU No. 31 Tahun 1999. Tetapi ketentuan ini tidak pernah digunakan JPU untuk mengajukan pelaku korporasi dalam tindak pidana korupsi ke pengadilan. Perkara tindak pidana korupsi di Pengadilan Negeri Kelas IA Tanjungkarang No. 22/PID.TPK/2011/PNTK ${ }^{20}$ a.n. Terdakwa Sugiarto Wiharjo alias Alay merupakan perkara dengan pelaku korporasi. Terdakwa selaku Komisaris Utama PT BPR Tripanca

\footnotetext{
Ibid, hlm. 20 .

10 Pengadilan Tindak Pidana Korupsi Jakarta menyidangkan pengusaha SHM yang diduga melakukan tindak pidana korupsi suap kepada Bupati Buol Amran Batalipu.

$1 \quad$ KPK menahan Irjen (Pol.) DS seorang Jenderal Polri aktif sebagai tersangka kasus Simulator SIM Mabes Polri.

12 Penyidik di Kejaksaan Agung melimpahkan berkas perkara tersangka/terdakwa IA dan barang bukti kasus penyalahgunaan frekuensi 2,1 Ghz/3 G PT. Indosat Mega Media (IM2) kepada Penuntut Umum di Kejaksaan Negeri Jakarta Selatan

3 Terdakwa M. Nazarudin divonis penjara 4 tahun 10 bulan oleh Pengadilan Tipikor Jakarta.

14 Kasus Sisminbakum melibatkan pejabat-pejabat di Depkumham RI dan PT. SRD.

15 Pasal 1 angka 1 Undang-Undang No. 31 Tahun 1999: Korporasi adalah kumpulan orang dan atau kekayaan yang terorganisasi baik merupakan badan hukum maupun bukan badan hukum.

16 Pihak terafiliasi adalah pihak yang turut bertanggungjawab dalam korporasi perbankan. Lihat Pasal 40 Undang-Undang No. 10 Tahun 1998 tentang Perubahan Undang-Undang No. 7 Tahun 1992 tentang Perbankan.

7 Undang-Undang No. 40 Tahun 2007 tentang Perseroan Terbatas mengatur tentang pertanggungjawaban pemegang saham (Pasal 3).

8 Eddy Rifai, 2002, Pemberantasan Tindak Pidana Korupsi, PPS Magister Hukum Unila, Bandar Lampung, hlm. 62.

19 Muladi dan Dwidja Priyatno, 2010, Pertanggungjawaban Korporasi dalam Hukum Pidana, Kencana Prenada Media Group, Jakarta, hlm. 10.

20 Perkara telah berkekuatan hukum tetap (in kracht van gewijsde). Lihat Eddy Rifai, A. Zazili, dan A. Irzal F., 2012, Laporan Eksaminasi Putusan Perkara No. 22/PID.TPK/2011/PNTK a.n. Terdakwa Sugiharto Wiharjo Alias Alay Kerjasama FH Unila-KPK, Fakultas Hukum Unila, Bandar Lampung, hlm. 2.
} 
Setiadana bersama-sama dengan saksi St (selaku Bupati Lampung Timur) antara tahun 2005 s.d. 2008 melakukan atau turut serta melakukan beberapa perbuatan tindak pidana korupsi meskipun masing-masing merupakan kejahatan atau pelanggaran yang ada hubungannya sedemikian rupa sehingga harus dipandang sebagai perbuatan berlanjut dengan cara Terdakwa menemui saksi St menawarkan untuk menyimpan sebagian dana Kas Daerah Kab. Lampung Timur dalam bentuk tabungan di PT BPR Tripanca Setiadana yang disetujui oleh saksi. Terdakwa menawarkan bunga yang lebih tinggi yaitu antara 7,5\%8,5\% untuk Pemkab Lampung Timur dan bunga tambahan 0,45\%-0,50\% untuk saksi. Perbuatan Terdakwa telah merugikan keuangan negara c.q. Keuangan Daerah Pemkab Lampung Timur sebesar Rp119.448.199.800.

Dalam proses terjadinya tindak pidana korupsi sebagaimana keterangan saksi-saksi dan terdakwa di pengadilan melibatkan pengurus-pengurus PT BPR Tripanca Setiadana lainnya seperti direktur utama, direktur, dan staf/pegawai. Tetapi dalam perkara ini hanya terdakwa (Komisaris Utama) yang dijadikan terdakwa, sedangkan pengurus lainnya tidak baik dalam bertanggungjawab sebagai pengurus korporasi maupun secara perorangan dengan menggunakan Pasal 55 KUHP. Jaksa Penuntut Umum (JPU) mendakwa terdakwa dengan Dakwaan Primair: Melanggar Pasal 2 ayat (1) jo. Pasal 18 UU No. 31 Tahun 1999 tentang Pemberantasan Korupsi yang dirubah dan ditambah dengan UU No. 20 Tahun 2001 jo. Pasal 55 ayat (1) ke-1 KUHP jo. Pasal 64 ayat (1) KUHP. Dakwaan Subsidair: Melanggar Pasal 3 jo. Pasal 18 UU No. 31 Tahun 1999 tentang Pemberantasan Korupsi yang dirubah dan ditambah dengan UU No. 20 Tahun 2001 jo. Pasal 55 ayat (1) ke-1 KUHP jo Pasal 64 ayat (1) KUHP. Dakwaan Lebih Subsidair: Melanggar Pasal 5 ayat (1) jo. Pasal 18 UU No. 31 Tahun 1999 tentang Pemberantasan Korupsi yang dirubah dan ditambah dengan UU No. 20 Tahun 2001 jo. Pasal 55 ayat (1) ke-1 KUHP jo. Pasal 64 ayat (1) KUHP. Masalah dalam penelitian ini adalah: Pertama, bagaimana pertanggungjawaban pidana korporasi dalam tindak pidana korupsi?; Kedua, apakah faktor penghambat pertanggungjawaban pidana korporasi dalam tindak pidana korupsi?; Ketiga, bagaimana perspektif pertanggungjawaban pidana korporasi dalam tindak pidana korupsi?

\section{B. Metode Penelitian}

Tipe penelitian yang digunakan adalah bersifat deskriptif analitis yaitu penelitian yang berusaha untuk menggambarkan dan menguraikan tentang persoalan yang berkaitan dengan pertanggungjawaban pidana terhadap korporasi yang melakukan tindak pidana korupsi, faktor penghambat pertanggungjawaban pidana korporasi yang melakukan tindak pidana korupsi dan perspektif pertanggungjawaban pidana terhadap korporasi yang melakukan tindak pidana korupsi. Pendekatan yang digunakan adalah pendekatan yuridis normatif dan yuridis empiris. Pendekatan yuridis normatif yaitu pendekatan yang didasarkan pada peraturan perundang-undangan, teoriteori dan konsep-konsep yang berhubungan dengan penulisan penelitian, sedangkan pendekatan yuridis empiris yang dilakukan dengan mengadakan penelitian lapangan, yaitu dengan melihat fakta-fakta yang ada dalam praktik dan mengenai pelaksanaannya.

Dalam kaitan dengan penelitian normatif, pendekatan yang digunakan adalah: (a) pendekatan perundang-undangan (statute approach), yaitu suatu pendekatan yang dilakukan terhadap berbagai aturan hukum yang berkaitan dengan tindak pidana perikanan seperti Undang-Undang Nomor 20 Tahun 2001 tentang Perubahan Undang-Undang Nomor 31 Tahun 1999 tentang Pemberantasan Tindak Pidana Korupsi; Undang-Undang Nomor 8 Tahun 1981 tentang Kitab UndangUndang Hukum Acara Pidana; Undang-Undang Nomor 48 Tahun 2009 tentang Kekuasaan Kehakiman; Undang-Undang Nomor 40 Tahun 2007 tentang Perseroan Terbatas dan beberapa peraturan pelaksanaan yang berhubungan dengan objek penelitian; (b) pendekatan konsep (conceptual approach) digunakan untuk memahami konsep-kon- 
sep tentang: pertanggungjawaban pidana, korporasi dan tindak pidana korupsi. Dengan adanya konsep yang jelas maka diharapkan penormaan dalam aturan hukum tidak lagi terjadi pemahaman yang kabur dan ambigu.

Dalam penelitian ini, populasi terdiri dari hakim pengadilan negeri, jaksa kejaksaan negeri, pengacara/penasehat hukum, dan teoritis/akademisi. Untuk menentukan sampel dari populasi di atas digunakan metode proportional purposive sampling yang berarti bahwa dalam menentukan sampel disesuaikan dengan tujuan yang hendak dicapai dan proporsi masing-masing sampel yang dianggap telah mewakili populasi terhadap masalah yang hendak diteliti/dibahas. Sesuai dengan metode penentuan sampel dari populasi yang akan diteliti sebagaimana tersebut di atas maka sampel dalam membahas penelitian ini adalah: 1 orang hakim Pengadilan Negeri Kelas IA Tanjungkarang; 1 orang jaksa Kejaksaan Negeri Bandar Lampung; 1 orang pengacara/penasehat hukum; dan 1 orang teoritis/ akademisi. Untuk menganalisis data yang telah terkumpul penulis menggunakan analisis kualitatif. Analisis kualitatif dilakukan untuk melukiskan kenyataan-kenyataan yang ada berdasarkan hasil penelitian yang berbentuk penjelasan-penjelasan, dari analisis tersebut dapat ditarik suatu kesimpulan secara induktif, yaitu cara berpikir dalam mengambil suatu kesimpulan terhadap permasalahan yang membahas secara umum yang didasarkan atas fakta-fakta yang bersifat khusus.

\section{Hasil Penelitian dan Pembahasan \\ 1. Pertanggungjawaban Korporasi dalam Tindak Pidana Korupsi}

Perkara pada Pengadilan Negeri Kelas IA Tanjungkarang No. 22/PID.TPK/2011/PNTK dengan terdakwa Sugiharto Wiharjo alias Alay terdapat 2 persoalan yang terkait dengan pertanggungjawaban pidana korporasi, yaitu mengenai unsur (1) setiap orang dan (2) bersama-sama melakukan tindak pidana. Pengacara/Penasehat Hukum terdakwa baik dalam eksepsi/keberatan dan pledoi/pembelaan dengan didukung saksi ahli yang dihadirkan di persidangan yaitu Prof. Dr. Yusril Ihza Mahendra, SH, MA (Guru Besar FH UI) dan Prof. Dr. Sri Redjeki Hartono, SH (Guru Besar FH Undip) menyatakan pertanggungjawaban pidana tidak dapat dipertanggungjawabkan kepada terdakwa secara orang-perorang, melainkan merupakan pertanggungjawaban korporasi, karena perbuatan terdakwa dilakukan dalam kapasitasnya sebagai Komisaris Utama PT. BPR Tripanca Setiadana. Perbuatan itu tidak akan terjadi, tanpa ada perbuatan pengurus bank lainnya seperti Direktur Utama, Direktur dan staf/pegawai.

Dakwaan Jaksa Penuntut Umum (JPU) terhadap terdakwa berbentuk subsidiaritas. Oleh karena itu, Majelis Hakim mempertimbangkan dakwaan primair terlebih dulu. Dakwaan primair melanggar Pasal 2 ayat (1) jo. Pasal 18 UU No. 31 Tahun 1999 tentang Pemberantasan Korupsi yang dirubah dan ditambah dengan UU No. 20 Tahun 2001 jo. Pasal 55 ayat (1) ke-1 KUHP jo. Pasal 64 ayat (1) KUHP, dengan unsur-unsur sebagai berikut: (1) setiap orang; (2) secara melawan hukum; (3) melakukan perbuatan memperkaya diri sendiri atau orang lain atau suatu korporasi; (4) dapat merugikan keuangan negara atau perekonomian negara; (5) dilakukan secara bersama-sama; (6) melakukan beberapa perbuatan masing-masing merupakan kejahatan atau pelanggaran yang ada hubungannya sedemikian rupa sehingga harus dipandang sebagai suatu perbuatan berlanjut.

Dalam pertimbangan hakim tentang unsur "setiap orang" menyatakan bahwa dalam Pasal 21 UU No. 31 Tahun 1999 tidak ditentukan adanya suatu syarat yang menyertai kata setiap orang tersebut. Oleh karenanya sesuai dengan pengertian yang diberikan dalam Pasal 1 angka 3 di atas, maka subyek pelaku tindak pidana sebagaimana dimaksud dalam Pasal 2 ini dapat berupa "orang-perorangan" dan/atau "korporasi", sedangkan pengertian "korporasi" itu sendiri adalah kumpulan orang dan atau kekayaan yang berorganisasi, baik merupakan badan hukum maupun bukan badan hukum. Bahwa kata "setiap orang" ini sepadan dengan kata "barang siapa" (hij) yang biasa tercantum dalam suatu 
perumusan delik, yakni suatu istilah yang bukan merupakan unsur tindak pidana, melainkan merupakan unsur pasal, yang menunjuk kepada siapa saja secara perorangan atau suatu badan hukum sebagai pendukung hak dan kewajiban yang melakukan atau telah didakwa melakukan suatu perbuatan yang dilarang oleh peraturan perundang-undangan. "Setiap orang" ini melekat pada setiap unsur tindak pidana, oleh karenanya ia akan terpenuhi dan terbukti apabila semua unsur tindak pidana dalam delik tersebut terbukti dan pelakunya dapat dimintai pertanggungjawaban pidana. Menimbang bahwa di depan persidangan, JPU telah menghadapkan seorang laki-laki yang bernama Sugiharto Wiharjo alias Alay dengan segala identitasnya sebagaimana tertera dalam dakwaan JPU dan bersesuaian dengan hasil pemeriksaan di persidangan, Majelis Hakim berkeyakinan bahwa unsur "setiap orang" telah terpenuhi.

Pertimbangan hakim dalam unsur tindak pidana dilakukan bersama-sama (Pasal 55 ayat (1) ke-1 KUHP) menyatakan delik penyertaan diatur dalam Pasal 55 dan 56 KUHP. Berdasarkan pasalpasal tersebut penyertaan dibagi: (a) Pembuat/dader (Pasal 55) yang terdiri dari: (1) pelaku (pleger); (2) yang menyuruh lakukan (doenpleger); (3) yang turut serta (medepleger); (4) penganjur (uitlokker); (b) Pembantu/medeplichtige (Pasal 56) yang terdiri dari pembantu pada saat kejahatan dilakukan dan pembantu sebelum kejahatan dilakukan. Menimbang bahwa pengertian "turut melakukan" menurut Simon adalah orang lain yang "turut serta" melakukan kejahatan itu dapat dianggap sebagai pelaku, maka dengan demikian dapat terjadi medepleger atau turut serta melakukan tindak pidana. Mededaderschap itu menunjukkan tentang adanya kerja sama secara fisik untuk melakukan suatu perbuatan, kerja sama fisik itu haruslah didasarkan pada kesadaran bahwa mereka itu bekerjasama.

Bahwa adanya kerja sama yang erat antara terdakwa selaku pribadi yang saat itu menjabat Komisaris Utama PT BPR Tripanca Setiadana dengan saksi St (mantan Bupati Lampung Timur), dimana terdakwa mengadakan pertemuan dengan saksi dan menawarkan bunga yang lebih tinggi serta fasilitas bunga tambahan kepada saksi untuk menempatkan Dana Kas Daerah Kab. Lampung Timur ke PT BPR Tripanca Setiadana. Kemudian saksi membuat SK Bupati dan memerintahkan staf Bagian Keuangan Pemkab Lampung Timur untuk menempatkan sebagian Dana Kas Daerah Kab. Lampung Timur ke PT BPR Tripanca Setiadana, dimana proses penempatan dana dilakukan oleh staf/ pegawai PT BPR Tripanca Setiadana.

Menurut Sopian Sitepu ${ }^{21}$ pertimbangan hakim tidak mempertimbangkan keterangan saksi ahli dari Prof. Dr. Yusril Ihza Mahendra, SH, MA dan Prof. Dr. Sri Redjeki Hartono, SH yang antara lain menyatakan bahwa tindak pidana ini merupakan tindak pidana dalam lingkup tindak pidana perbankan; surat audit penghitungan kerugian keuangan negara oleh BPKP telah dinyatakan cacat hukum dan tidak berkekuatan hukum mengikat oleh pengadilan, maka seharusnya tidak dapat diajukan sebagai alat bukti di pengadilan; terhadap adanya kesalahan perusahaan maka yang bertanggungjawab adalah korporasi perusahaan tersebut. Oleh karena itu, responden menyatakan pertimbangan hakim bahwa terdakwa "selaku pribadi" yang saat itu menjabat Komisaris Utama PT BPR Tripanca Setiadana adalah tidak logis. Perbuatan terdakwa menghubungi saksi St untuk menempatkan dana Kas Daerah Pemkab Lampung Timur adalah dalam kapasitasnya selaku Komisaris Utama PT BPR Tripanca Setiadana, karena setelah saksi menyetujui dan memindahkan dana, semua proses dilakukan oleh pengurus korporasi PT BPR Tripanca Setiadana dengan pembukuan yang sah/ legal. Apabila perbuatan dilakukan oleh terdakwa "selaku pribadi" maka penempatan dana itu akan dibukukan pada rekening pribadi terdakwa bukan pada pembukuan perusahaan.

Menurut Heru Wijatmiko ${ }^{22}$, responden jaksa pada Kejaksaan Tinggi Lampung, keengganan JPU

\footnotetext{
${ }^{21}$ Sopian Sitepu, SH, MH adalah Pengacara/Advokat pada Kantor Pengacara Sopian Sitepu and Partners di Bandar Lampung, wawancara dilakukan tanggal 20 Oktober 2012.

22 Heru Wijatmiko, SH, MH adalah jaksa pada Kejaksaan Tinggi Lampung, wawancara dilakukan tanggal tanggal 12 November 2012.
} 
untuk mendakwa terdakwa selaku orang-perorang dan bukan korporasi dalam tindak pidana korupsi; Pertama, karena pemidanaan yang akan dijatuhkan pengadilan terhadap korporasi tidak boleh berupa pidana mati atau pidana penjara, padahal pidana ini dengan sanksinya yang tajam diharapkan mempunyai efek jera terhadap pelaku dan memuaskan rasa keadilan masyarakat yang menginginkan pelaku dipenjara. Kedua, dalam pembuktian untuk membuktikan "kesalahan" korporasi dalam kaitan unsur "melawan hukum", JPU kesulitan mendapatkan teori-teori/doktrin dan dasar hukum tentang "kesalahan" korporasi yang ternyata banyak pertentangan pendapat di antara ahli hukum pidana. Berbeda dengan teori-teori/doktrin dan dasar hukum tentang "kesalahan" orang-perorang yang pada umumnya para ahli pidana sepakat bahwa hanya orang yang dapat memiliki unsur "kesalahan". Kekeliruan JPU membuktikan perbuatan sebagai kesalahan individu (natuurlijke persoon) dalam tindak pidana korporasi akan berakibat terdakwa diputus bebas (vrijspraak) oleh pengadilan.

Menurut Maroni ${ }^{23}$ pertanggungjawaban pidana dalam kasus Sugiharto Wiharjo alias Alay adalah pertanggungjawaban korporasi dan bukan pertanggungjawaban orang-perorang. Hal itu karena perbuatan terdakwa bersama-sama dengan saksi St (mantan Bupati Lampung Timur) dalam kapasitasnya selaku Komisaris Utama PT BPR Tripanca Setiadana dan bukan selaku pribadi. Menurut responden, memang perumusan dapat dipidananya suatu korporasi sejak lama telah menimbulkan pendapat pro dan kontra di kalangan para ahli hukum pidana. Dalam hukum pidana terdapat doktrin yang berkembang, yaitu doktrin "universitas delinguere non potest" yaitu korporasi tidak mungkin melakukan tindak pidana. Doktrin ini dipengaruhi pemikiran bahwa keberadaan korporasi dalam hukum pidana hanya fiksi hukum, sehingga tidak mempunyai nilai moral yang disyaratkan untuk dapat dipersalahkan secara pidana (unsur kesalahan). Padahal dalam suatu tindak pidana mensyaratkan adanya kesalahan (mens rea) selain adanya perbuatan (actus reus). Tetapi pada saat sekarang baik pada negara-negara Eropa Kontinental maupun Anglo-Saxon, doktrin ini telah banyak ditinggalkan, dengan antara lain tidak dimasukkannya unsur kesalahan dalam pasal tentang pertanggungjawaban korporasi sehingga korporasi dapat dipertanggungjawabkan secara pidana.

Berdasarkan uraian di atas dapat dikatakan bahwa pengaturan pidana tentang pertanggungjawaban pidana korporasi dalam tindak pidana korupsi telah diatur dalam peraturan perundangundangan tindak pidana korupsi tetapi jarang diterapkan dalam praktik. Keengganan Jaksa Penuntut Umum mengajukan pelaku korporasi ke pengadilan, karena pemidanaan yang akan dikenakan kepada korporasi hanya berupa pidana denda yang kurang mempunyai efek penjera daripada pidana mati atau penjara terhadap pelaku orang perorangan dan kesulitan pembuktian "kesalahan" korporasi sebagai bagian unsur melawan hukum daripada membuktikan kesalahan orang perorang. Para ahli pidana masih berbeda pendapat, sebagian menyatakan bahwa yang mempunyai kesalahan hanya orang (manusia), sedangkan sebagian lain menyatakan bahwa korporasi juga dapat mempunyai kesalahan. Apabila JPU salah dalam membuktikan kesalahan pelaku dalam tindak pidana korporasi sebagai kesalahan individu (natuurlijke presoon) dapat berakibat terdakwa diputus bebas (vrijspraak) oleh pengadilan.

\section{Faktor Penghambat Pertanggungjawaban Korporasi dalam Tindak Pidana Korupsi}

Munculnya persoalan pertanggungjawaban korporasi dalam hukum pidana, karena selama ini pertanggungjawaban pelaku tindak pidana dalam KUH Pidana hanya kepada orang. Menurut Bismar Nasution, ${ }^{24}$ tindak pidana (crime) dapat diidentifikasikan dengan timbulnya kerugian (harm), yang kemudian melahirkan pertanggungjawaban

23 Dr. Maroni, SH, MH adalah pengajar Bagian Hukum Pidana Fakultas Hukum Unila, wawancara dilakukan tanggal 5 Desember 2012.

24 Bismar Nasution, 4 Maret 2011, "Kejahatan Korporasi dan Pertanggungjawabannya", http://www.bismar.wordpress.com, diakses 26 Desember 2012 . 
pidana (criminal liability). Hal yang kemudian menimbulkan perdebatan adalah bagaimana pertanggungjawaban korporasi (corporate liability) mengingat bahwa dalam KUHPidana yang dianggap sebagai subyek hukum pidana hanyalah orang perseorangan dalam konotasi biologis yang alami (naturlijkee person). Jika seandainya kegiatan atau aktivitas yang dilakukan untuk dan atas nama suatu korporasi terbukti mengakibatkan kerugian dan harus diberikan sanksi, siapa yang akan pertanggungjawaban? Apakah pribadi korporasi itu sendiri atau para pengurusnya?

Formulasi pertanggungjawaban korporasi dalam tindak pidana korupsi memang tidak mudah diterapkan, karena dengan dijadikannya korporasi (badan hukum) sebagai subyek tindak pidana, maka sistem pidana dan pemidanaannya juga seharusnya berorientasi pada korporasi. Ini berarti perlu ada reformulasi pengaturan pidana: ${ }^{25}$

a. Kapan korporasi melakukan tindak pidana dan kapan dipertanggungjawabkan. Karena kebijakan selama ini ada yang merumuskan dan ada yang tidak merumuskan dalam aturan perundangundangan.

b. Siapa yang dapat dipertanggungjawabkan juga ada yang merumuskan dan ada yang tidak. Untuk yang akan datang maka kebijakan legislasi tentang siapa yang dapat dipertanggungjawabkan dalam korporasi harus diatur dengan tegas.

c. Jenis sanksi, harus dirumuskan kembali secara jelas dan terinci baik menyangkut jenis pidananya baik itu berupa pidana pokok, pidana tambahan dan tindakan tata tertib serta jenis-jenis sanksi dari pidana tersebut. Termasuk pilihan model pemidanaan yaitu apakah pidana yang diberlakukan untuk korporasi diatur berbeda dengan jenis sanksi untuk subyek tindak pidana berupa "manusia" ataukah akan dilakukan pemisahan, artinya pemidanaan khusus untuk korporasi diatur secara tersendiri.

d. Perumusan sanksinya juga harus jelas dan konsisten sehingga dapat diterapkan terhadap korporasi.

e. Apabila untuk yang akan datang, korporasi menjadi subjek tindak pidana secara umum, dan diatur dalam KUHP, maka perlu adanya pengaturan pemidanaan yang berlaku secara umum untuk korporasi.

Konsekuensi logis tentang kedudukan korporasi sebagai badan hukum, membawa pengaruh terhadap tindak pidana yang dapat dilakukan korporasi terdapat beberapa pengecualian. Sehubungan dengan hal tersebut Barda Nawawi Arief ${ }^{26}$ menyatakan, walaupun pada asasnya korporasi dapat dipertanggungjawabkan sama dengan orang pribadi, namun ada beberapa pengecualian, yaitu: (a) dalam perkara-perkara yang menurut kodratnya tidak dapat dilakukan oleh korporasi misalnya bigami, perkosaan, sumpah palsu dan (b) dalam perkara yang satu-satunya pidana yang dapat dikenakan tidak mungkin dikenakan kepada korporasi misal pidana penjara atau pidana mati.

Dalam hukum pidana Indonesia, rumusan tentang korporasi pada awal mulanya terdapat pada Pasal 59 KUH Pidana: "Dalam hal-hal dimana karena pelanggaran ditentukan pidana terhadap pengurus, anggota-anggota badan pengurus atau komisaris-komisaris, maka pengurus, anggota badan pengurus atau komisaris yang ternyata tidak ikut campur melakukan pelanggaran tidak dipidana". Pasal ini, sekalipun merumuskan adanya pelanggaran pidana yang dilakukan korporasi, tetapi pasal ini juga membatasi pertanggungjawaban pidana terhadap pengurus korporasi yang bersalah. Hal ini karena KUH Pidana hanya menganut pertanggungjawaban orang perorang saja.

Dalam perkembangan kemudian timbul kesulitan dalam praktik, sebab di dalam pelbagai tindak pidana khusus timbul perkembangan yang pada dasarnya menganggap bahwa tindak pidana

\footnotetext{
25 Dwidja Priyatno, "Reorientasi dan Reformulasi Sistem Pertanggungjawaban Pidana Korporasi dalam Kebijakan Kriminal dan Kebijakan Pidana", http://www.wordpress.com, diakses 26 Desember 2012.

26 Barda Nawawi Arief, 1990, Perbandingan Hukum Pidana, Rajawali Pers, Jakarta, hlm. 37.
} 
juga dapat dilakukan oleh korporasi, mengingat kualitas keadaan yang hanya dimiliki oleh badan hukum atau korporasi tersebut. Akhirnya berdasarkan Pasal 91 KUHP Belanda, atau Pasal 103 KUHP Indonesia, diperbolehkan peraturan di luar KUHP untuk menyimpang dari Ketentuan Umum Buku I KUHP. Berdasarkan ketentuan itu maka lahirlah berbagai peraturan perundang-undangan di luar KUHP yang mengatur korporasi sebagai subjek hukum pidana yang dapat melakukan tindak pidana dan dapat dipertanggungjawabkan. Fenomena ini ditandai dengan lahirnya Wet Economische Delichten (WED), tahun 1950 di Belanda, yang dalam Pasal 15 ayat (1) mengatur bahwa dalam tindak pidana ekonomi, korporasi dapat melakukan tindak pidana dan dapat dipidana. Ketentuan ini kemudian ditiru oleh Indonesia melalui Undang-Undang Nomor 7 Drt Tahun 1955 tentang Pengusutan, Penuntutan dan Peradilan Tindak Pidana Ekonomi. ${ }^{27}$

Pasal 5 ayat (1) UU No. 7/Drt/1955 menentukan: "Jika suatu tindak pidana ekonomi dilakukan oleh atau atas nama suatu badan hukum, suatu perseroan suatu perserikatan orang yang lainnya atau suatu yayasan, maka tuntutan pidana dilakukan dan hukuman pidana serta tindakan tata tertib dijatuhkan baik terhadap badan hukum, perseroan, perserikatan atau yayasan itu, baik terhadap mereka yang memberi perintah melakukan tindak pidana ekonomi itu atau yang bertindak sebagai pemimpin dalam perbuatan atau kelalaian itu atau terhadap kedua-duanya". Pengaturan dalam UU No. 7/Drt/1955 menjadi cikal bakal pertanggungjawaban pidana korporasi dalam melakukan tindak pidana, yang kemudian diikuti beberapa peraturan perundang-undangan lain sampai dengan sekarang seperti UU Lingkungan Hidup, UU Perlindungan Konsumen, UU Perikanan, UU Narkotika, UU Pencucian Uang, UU Monopoli, UU Korupsi dan lain-lain. Tetapi, sekalipun banyak undang-undang mengatur tentang pertanggungjawaban korporasi, dalam praktik penerapannya di pengadilan sangat jarang korporasi diajukan sebagai pelaku tindak pidana.

Di Belanda ditetapkan bahwa badan hukum dalam hukum pidana dapat melakukan tindak pidana, oleh karena itu dapat dituntut dan dijatuhi hukuman, tetapi melalui tiga tahap tentang diakuinya badan hukum sebagai subyek hukum pidana: ${ }^{28}$

a. Pertama, tahap ini ditandai dengan usaha-usaha agar sifat tindak pidana yang dilakukan badan hukum dibatasi pada perorangan (naturlijk persoon), sehingga apabila suatu tindak pidana terjadi dalam suatu lingkungan badan hukum maka suatu tindak pidana dianggap dilakukan oleh pengurus badan hukum tersebut. Dalam tahap ini berlaku asas "universitas delinguere non potest" yaitu badan hukum tidak dapat melakukan suatu tindak pidana. Pertanggungjawaban disini hanya berkaitan dengan kewajiban memelihara yang dilakukan oleh pengurus.

b. Kedua, tahap ini bahwa suatu tidak pidana dapat dilakukan oleh badan hukum, tetapi tanggungjawab telah dibebankan kepada pengurus badan hukum tersebut. Perumusan khusus untuk badan hukum tersebut yakni apabila suatu tindak pidana dilakukan oleh atau karena suatu badan hukum, tuntutan pidana dan hukuman pidana harus dijatuhkan pada pengurus. Jadi dalam hal ini orang bersikap bahwa seolah-olah badan hukum dapat melakukan tindak pidana tetap secara riel yang melakukan perbuatan adalah manusia sebagai wakil-wakilnya.

c. Ketiga, tahap ini merupakan permulaan adanya tanggung jawab langsung badan hukum, secara kumulatif badan hukum dapat dipertanggungjawabkan menurut hukum pidana di samping mereka sebagai pemberi perintah mereka yang sebagai pemberi perintah atau pemberi pimpinan yang nyata telah berperan pada tindak pidana

Muladi, 1999, Penerapan Pertanggungjawaban Korporasi dalam Hukum Pidana, Bahan Kuliah Kejahatan Korporasi, Universitas Diponegoro, Semarang, hlm. 2.

28 Hamzah Hatrik, 1996, Asas Pertanggungjawaban Korporasi dalam Hukum Pidana Indonesia (Strict Liability dan Vicarious Liability), Raja Grafindo Persada, Jakarta, hlm. 107. 
itu. Hal ini terjadi pertama kali untuk "ondering strafrecht" yaitu keputusan pengendalian harga dari tahu 1941, kemudian dalam "Wet op de Economische Delicten" (Undang-Undang Tindak Pidana Ekonomi Tahun 1950).

Pengaturan korporasi sebagai pelaku tindak pidana korupsi di Indonesia diatur dalam Pasal 20 UU No. 31 Tahun 1999 sebagai berikut:

(1) Dalam hal tindak pidana korupsi dilakukan oleh atau atas nama suatu korporasi, maka tuntutan dan penjatuhan pidana dapat dilakukan terhadap korporasi dan pengurusnya.

(2) Tindak pidana korupsi dilakukan oleh korporasi apabila tindak pidana tersebut dilakukan oleh orang-orang baik berdasarkan hubungan kerja maupun berdasarkan hubungan lain, bertindak dalam lingkungan korporasi tersebut baik sendiri maupun bersama-sama.

(3) Dalam hal tuntutan pidana dilakukan terhadap suatu korporasi, maka korporasi tersebut diwakili oleh pengurus.

(4) Pengurus yang mewakili korporasi sebagaimana dimaksud dalam ayat (3) dapat diwakili oleh orang lain.

(5) Hakim dapat memerintahkan supaya pengurus korporasi menghadap sendiri di pengadilan dan dapat pula memerintahkan supaya pengurus tersebut dibawa ke sidang pengadilan.

(6) Dalam hal tuntutan pidana dilakukan terhadap korporasi, maka panggilan untuk menghadap dan penyerahan surat panggilan tersebut disampaikan kepada pengurus di tempat tinggal pengurus atau tempat pengurus berkantor.

(7) Pidana pokok yang dapat dijatuhkan terhadap korporasi hanya pidana denda dengan ketentuan maksimum pidana ditambah $1 / 3$ (sepertiga).

Berdasarkan ketentuan di atas dapat diartikan bahwa aturan pidana tentang korporasi sebagai pelaku tindak pidana korupsi adalah: (a) tindak pidana korupsi yang dilakukan oleh korporasi, penjatuhan pidana terhadap korporasi dan pengurusnya; (b) tindak pidana korporasi yang dilakukan korpo- rasi apabila tindak pidana dilakukan oleh orangorang berdasarkan hubungan kerja atau hubungan lain, bertindak dalam lingkungan korporasi tersebut baik sendiri maupun bersama-sama; (c) dalam hal tuntutan pidana, korporasi diwakili oleh pengurus atau orang lain; dan (d) pidana berupa denda. Kelemahan dari pengaturan pidana korporasi sebagai pelaku tindak pidana dan pertanggungjawaban pidana dalam tindak pidana korupsi adalah: (a) tidak mengatur tentang bagaimana dan kapan korporasi melakukan tindak pidana; (b) tidak ada spesifikasi yang tegas dan detail tentang pertanggungjawaban pidana korporasi, apakah pertanggungjawaban pidana terhadap korporasi atau terhadap pengurusnya; (c) penuntutan terhadap korporasi dapat diwakili orang lain; dan (d) jenis sanksi hanya berupa pidana denda yang berkualifikasi sama terhadap sanksi terhadap orang perorangan (manusia).

Faktor penghambat dari pertanggungjawaban pidana korporasi dalam tindak pidana korupsi adalah kelemahan peraturan perundang-undangan tindak pidana korupsi yang tidak menentukan bagaimana dan kapan korporasi melakukan tindak pidana korupsi; tidak ada spesifikasi yang tegas dan detail tentang pertanggungjawaban pidana korporasi, apakah pertanggungjawaban pidana terhadap korporasi atau terhadap pengurusnya; dan jenis sanksi hanya berupa pidana denda yang berkualifikasi sama terhadap sanksi terhadap orang perorangan (manusia).

\section{Perspektif Pertanggungjawaban Pidana Korporasi dalam Tindak Pidana Korupsi}

Pada negara-negara Eropa Kontinental, seperti di Belanda ${ }^{29}$ pengaturan pertanggungjawaban korporasi terdapat dalam Ketentuan Umum KUHP, sehingga tidak perlu diatur secara tersebar di luar KUHP (WvS Belanda), sebab dengan lahirnya Undang-Undang tanggal 23 Juni 1976 Stb. 377, yang disahkan tanggal 1 September 1976, muncul perumusan baru Pasal 51 WvS Belanda yang merumuskan:

(1) Tindak pidana dapat dilakukan oleh manusia alamiah dan badan hukum. 
(2) Apabila suatu tindak pidana dilakukan oleh badan hukum, dapat dilakukan tuntutan pidana dan jika dianggap perlu dapat dijatuhkan pidana dan tindakan-tindakan yang tercantum dalam undang-undang terhadap: badan hukum atau terhadap yang "memerintah" melakukan tindakan yang dilarang itu; atau terhadap mereka yang bertindak sebagai "pemimpin" melakukan tindakan yang dilarang itu; terhadap "badan hukum" dan "yang memerintahkan melakukan perbuatan" di atas bersama-sama.

(3) Bagi pemakai ayat selebihnya disamakan dengan badan hukum: perseroan tanpa badan hukum, perserikatan, dan yayasan.

Dengan lahirnya undang-undang ini maka semua ketentuan peraturan perundang-undangan pidana khusus yang tersebar di luar KUHP Belanda yang mengatur tentang pertanggungjawaban pidana korporasi dicabut karena dipandang tidak perlu lagi, sebab dengan diaturnya pertanggungjawaban korporasi dalam Pasal 51 KUHP Belanda, maka sebagai Ketentuan umum berdasarkan Pasal 91 KUHP Belanda (Pasal 103 KUHP Indonesia), ketentuan ini berlaku untuk semua peraturan di luar kodifikasi sepanjang tidak disimpangi. Di Jerman berkembang suatu teori, untuk memidana badan hukum tanpa mensyaratkan kesalahan, yang berasal dari Schunemann. ${ }^{30}$ Menurutnya, badan hukum tidak mungkin dinyatakan bersalah. Namun pemidanaan terhadap badan hukum dapat dilakukan. Menurut pandangannya Schuldgrundsatz dapat digantikan oleh prinsip legitimasi lainnya yaitu apa yang dinamakan Rechtsguternotstand. Rechtsguternotstand mempunyai pengertian "yaitu bilamana ada kemungkinan objek-objek hukum penting tertentu terancam dan perlindungannya hanya dapat diberikan dengan cara menjatuhkan pidana pada badan hukum".

Jika penjatuhan pidana hendak didasarkan pada suatu Rechtsguternotstand, maka menurut
Schunemann, masih harus dipenuhi beberapa syarat tertentu. Syarat-syarat yang terpenting adalah sebagai berikut: (a) pidana harus punya daya kerja preventif; (b) kepentingan daya kerja preventif harus lebih besar dibanding kepentingan integritas finansial dari perusahaan; dan (c) tidak mungkin untuk menghukum subyek hukum manusia karena dalam kenyataan tindak pidana dilakukan dalam suatu ikatan perusahaan.

Pada negara-negara Anglo Saxon menggunakan doktrin pertanggungjawaban pidana langsung (direct liability doctrine) atau teori identifikasi (identification theory) perbuatan/kesalahan "pejabat" senior (senior officer) diidentifikasikan sebagai perbuatan/kesalahan korporasi. Disebut juga teori/doktrin "alter ego" atau teori organ dalam arti sempit (Inggris) hanya perbuatan pejabat senior (otak korporasi) yang dapat dipertanggungjawabkan kepada korporasi. Dalam arti luas (Amerika Serikat) tidak hanya pejabat senior/direktur, tetapi juga agen di bawahnya. Ada beberapa pendapat untuk mengidentifikasikan "senior officer". Pada umumnya pejabat senior adalah orang yang mengendalikan perusahaan, baik sendiri maupun bersama-sama pada umumnya pada pengendali perusahaan adalah direktur dan manager.

Doktrin pertanggungjawaban korporasi dalam suatu tindak pidana yang mendasarkan pada teori identifikasi: ${ }^{31}$

a. Hakim Ried dalam perkara Tesco Supermarkets (1972) menyatakan bahwa untuk tujuan hukum, para pejabat senior biasanya terdiri dari "Dewan Direktur, Direktur Pelaksana, dan pejabat-pejabat tinggi lainnya yang melaksanakan fungsi manajemen dan berbicara serta berbuat untuk perusahaan". Konsep pejabat senior tidak mencakup semua pegawai perusahaan yang bekerja atau melaksanakan petunjuk pejabat tinggi perusahaan.

b. Lord Morris mengemukakan bahwa pejabat senior adalah orang yang tanggungjawabnya/melambangkan pelaksana dari "the directing mind and will

\footnotetext{
30 Dikutip dari Dwidja Priyatno, Loc. cit.

31 Barda Nawawi Arief, 2003, Kapita Selekta Hukum Pidana, RajaGrafindo, Jakarta, hlm. 170.
} 
of the company".

c. Viscount Dilhorne menyatakan bahwa pejabat senior adalah seorang yang dalam kenyataannya mengendalikan jalannya perusahaan (atau ia merupakan bagian dari para pengendali) dan ia tidak bertanggungjawab pada orang lain dalam perusahaan itu.

d. Hakim Nimmo J. (hakim ke-3 dalam perkara Universal Telecasters) dimana manajer penjualan dapat diidentifikasikan sebagai perusahaan, yaitu sebagai Senior Officer. Walaupun orang itu (Manajer Penjualan) tidak memiliki kekuasaan manajemen yang umum, tetapi ia memiliki kebijaksanaan manajerial (managerial discretion) yang relevan dengan bidang operasi perusahaan yang menyebabkan timbulnya delik. Dengan kata lain, dalam pandangannya pejabat perusahaan dapat menjadi senior officer dalam bidang yang relevan walaupun tidak untuk semua tujuan.

e. Supreme Court Queensland memutuskan bahwa manajer perusahaan menjual motor (motor dealer) dapat dipandang sebagai senior cation dan doktrin vicarious liability, yaitu dalam hal korporasi melanggar atau tidak memenuhi kewajiban/situasi tertentu yang ditentukan oleh undang-undang. Pelanggaran/kondisi/situasi tertentu oleh korporasi ini dikenal dengan istilah companies offences, situational offence, atau strict liability offences. Misal undang-undang menetapkan sebagai suatu delik bagi: Korporasi yang menjalankan usahanya tanpa izin, korporasi pemegang izin yang melanggar syarat-syarat (kondisi/situasi) yang ditentukan dalam izin itu, korporasi yang mengoperasikan kendaraan yang tidak diasuransikan di jalan umum.

Pada negara-negara Anglo-Saxon juga menggunakan doktrin-doktrin pertanggungjawaban pidana korporasi ${ }^{32}$

a. Doktrin Pertanggungjawaban Pengganti (vicarious liability):

1) Bertolak dari doktrin "respond- ent superior"; (catatan: arti dari "adagium/maxim" ini ialah: " $a$ master is liable in certain cases for the wrongful acts of his servant, and a principal for those of his agents").

2) didasarkan pada "employment principle", bahwa majikan ("employer") adalah penanggungjawab utama dari perbuatan para buruh/karyawan; jadi "the servant's act is the master's act in law".

3) Juga bisa didasarkan "the delegation principle". Jadi "a guilty mind" dari buruh/karyawan dapat dihubungkan ke majikan apabila ada pendelegasian kewenangan dan kewajiban yang relevan (harus ada "a relevan delegation of powers and duties") menurut undang-undang.

b. Doktrin pertanggungjawaban yang ketat menurut undang-undang ("strict liability"). Pertanggungjawaban korporasi dapat juga semata-mata berdasarkan undang-undang, terlepas dari doktrin "identification" dan doktrin "vicarious liability", yaitu dalam hal korporasi melanggar atau tidak memenuhi kewajiban/kondisi/situasi tertentu yang ditentukan oleh undang-undang. Pelanggaran kewajiban/ kondisi/situasi tertentu oleh korporasi ini dikenal dengan istilah "companies offence", "situational offence", atau "strict liability offences". Misal undang-undang menetapkan sebagai suatu delik bagi korporasi yang menjalankan usahanya tanpa izin;

1) Korporasi pemegang izin yang melanggar syarat-syarat (kondisi/situasi) yang ditentukan dalam izin itu;

2) Korporasi yang mengoperasikan kendaraan yang tidak diasuransikan di jalan umum.

Perspektif pertanggungjawaban pidana korporasi dalam tindak pidana korupsi adalah dengan merumuskan tindak pidana korporasi, pertang- 
gungjawaban pidana korporasi dan jenis sanksi pidana korporasi dalam Ketentuan Umum KUHP, sehingga dapat digunakan untuk semua peraturan perundang-undangan di luar KUHP (termasuk tindak pidana korupsi). Pengaturan pidana pertanggungjawaban korporasi juga dapat dibuat secara khusus dalam peraturan perundang-undangan tindak pidana korupsi. Formulasi pidana dan penegakan hukum pertanggungjawaban pidana korporasi dalam tindak pidana korupsi dapat menggunakan pada teori-teori/doktrin yang berkembang seperti teori/doktrin identifikasi, teori/doktrin vicarious liability (pertanggungjawaban pengganti) atau teori/doktrin strict liability (pertanggungjawaban ketat).

\section{Kesimpulan}

Pengaturan pidana tentang pertanggungjawaban pidana korporasi dalam tindak pidana korupsi telah diatur dalam peraturan perundangundangan tindak pidana korupsi tetapi jarang diterapkan dalam praktik. Keengganan Jaksa Penuntut Umum (JPU) mengajukan pelaku korporasi ke pengadilan, karena pemidanaan yang akan dikenakan kepada korporasi hanya berupa pidana denda yang kurang mempunyai efek penjera daripada pidana mati atau penjara terhadap pelaku orang perorangan dan kesulitan pembuktian "kesalahan" korporasi sebagai bagian unsur melawan hukum daripada membuktikan kesalahan orang perorang. Para ahli pidana masih berbeda pendapat, sebagian menyatakan bahwa yang mempunyai kesalahan hanya orang (manusia), sedangkan sebagian lain menyatakan bahwa korporasi juga dapat mempunyai kesalahan. Kekeliruan JPU dalam membuktikan kesalahan korporasi sebagai kesalahan individu akan berakibat terdakwa divonis bebas oleh pengadilan.

Faktor penghambat dari pertanggungjawaban pidana korporasi dalam tindak pidana korupsi adalah kelemahan peraturan perundang-undangan tindak pidana korupsi yang tidak menentukan bagaimana dan kapan korporasi melakukan tindak pidana korupsi; tidak ada spesifikasi yang tegas dan detail tentang pertanggungjawaban pidana korporasi, apakah pertanggungjawaban pidana terhadap korporasi atau terhadap pengurusnya; dan jenis sanksi hanya berupa pidana denda yang berkualifikasi sama terhadap sanksi terhadap orang perorangan (manusia). Perspektif pertanggungjawaban pidana korporasi dalam tindak pidana korupsi adalah dengan merumuskan tindak pidana korporasi, pertanggungjawaban pidana korporasi dan jenis sanksi pidana korporasi dalam Ketentuan Umum KUHP, sehingga dapat digunakan untuk semua peraturan perundangundangan di luar KUHP (termasuk tindak pidana korupsi). Pengaturan pidana pertanggungjawaban korporasi juga dapat dibuat secara khusus dalam peraturan perundang-undangan tindak pidana korupsi. Formulasi pidana dan penegakan hukum pertanggungjawaban pidana korporasi dalam tindak pidana korupsi dapat menggunakan teori-teori/doktrin yang berkembang seperti teori/doktrin identifikasi, teori/doktrin vicarious liability (pertanggungjawaban pengganti) atau teori/doktrin strict liability (pertanggungjawaban ketat).

\section{DAFTAR PUSTAKA}

\section{A. Buku}

Arief, Barda Nawawi, 1990, Perbandingan Hukum Pidana, Rajawali Pers, Jakarta. , 1996, Bunga Rampai Kebijakan Hukum Pidana, Alumni, Bandung. , 2003, Kapita Selekta Hukum Pidana, Raja Grafindo, Jakarta.

Hatrik, Hamzah, 1996, Asas Pertanggungjawaban
Korporasi dalam Hukum Pidana Indonesia (Strict Liability dan Vicarious Liability), Raja Grafindo Persada, Jakarta.

Lopa, Baharuddin, 2001, Kejahatan Korupsi dan Penegakan Hukum, Penerbit Buku KOMPAS, Jakarta.

Muladi, 1999, Penerapan Pertanggungjawaban Korporasi dalam Hukum Pidana, Bahan 
Kuliah Kejahatan Korporasi, Fakultas Hukum Universitas Diponegoro, Semarang.

Muladi dan Dwidja Priyatno, 2010, Pertanggungjawaban Korporasi dalam Hukum Pidana, Kencana Prenada Media Group, Jakarta.

Rifai, Eddy, 2002, Pemberantasan Tindak Pidana Korupsi, PPS Magister Hukum Unila, Bandar Lampung.

Rifai, Eddy, A. Zazili, dan A. Irzal F., 2012, Laporan Eksaminasi Putusan Perkara No. 22/ PID.TPK/2011/PNTK a.n. Terdakwa Sugiharto Wiharjo Alias Alay Kerjasama FH Unila-KPK. Fakultas Hukum Universitas Lampung, Bandar Lampung.

\section{B. Artikel dalam Antologi}

Bruselas, Apolinario D. "Corruption: The Philippine Experience" dalam UNAFEI, 1998, Resource Material Series No. 52, Tokyo.

\section{Sumber Internet}

Nasution, Bismar, 4 Maret 2011, "Kejahatan Korporasi dan Pertanggungjawabannya", http:// www.bismar.wordpress.com, diakses 26 De- sember 2012.

Priyatno, Dwidja, "Reorientasi dan Reformulasi Sistem Pertanggungjawaban Pidana Korporasi dalam Kebijakan Kriminal dan Kebijakan Pidana", http://www.wordpress.com, diakses 26 Desember 2012.

\section{Peraturan Perundang-Undangan}

Undang-Undang No. 10 Tahun 1998 tentang Perubahan Atas Undang-Undang Nomor 7 Tahun 1992 tentang Perbankan (Lembaran Negara Republik Indonesia Tahun 1998 Nomor 182). Undang-Undang No. 31 Tahun 1999 tentang Tindak Pidana Korupsi (Lembaran Negara Republik Indonesia Tahun 1999 Nomor 140).

Undang-Undang Nomor 20 Tahun 2001 tentang Perubahan Undang-Undang Nomor 31 Tahun 1999 tentang Pemberantasan Tindak Pidana Korupsi (Tambahan Lembaran Negara Republik Indonesia Nomor 4150).

Undang-Undang No. 40 Tahun 2007 tentang Perseroan Terbatas (Lembaran Negara Republik Indonesia Tahun 2007 Nomor 106). 